\title{
Prototheca richardsi, a pathogen of anuran larvae, is related to a clade of protistan parasites near the animal-fungal divergence
}

\author{
Gillian C. Baker, ${ }^{1}$ Trevor J. C. Beebee ${ }^{1}$ and Mark A. Ragan ${ }^{2,3}$ \\ Author for correspondence: Trevor J. C. Beebee. Tel: +44 1273 606755. Fax: +441273678433. \\ e-mail: t.j.c.beebee@sussex.ac.uk
}

School of Biological Sciences, University of Sussex, Falmer, Brighton BN1 9QG, UK

2,3 Canadian Institute for Advanced Research, Program in Evolutionary Biology2, and Institute for Marine Biosciences ${ }^{3}$, National Research Council of Canada, Halifax, Nova Scotia, Canada B3H $3 Z 1$

\begin{abstract}
Prototheca richardsi is a protist of uncertain taxonomy which mediates growth inhibition in anuran larvae. Cells of $P$. richardsi were isolated from tadpole faeces and DNA was purified by Qiagen chromatography. Nuclear smallsubunit (185) rDNA (ssu-rDNA) was amplified by PCR using universal primers, cloned, and six clones (two from each of three separate isolates) were sequenced. All clones yielded an essentially identical sequence of 1802 nucleotides. In situ hybridization of fluorescent Prototheca-specific oligonucleotide probes, designed using the derived 185 rDNA sequence, confirmed that the sequence was indeed from $P$. richardsi cells and not from other components of tadpole faeces. The $P$. richardsi sequence was aligned with ssu-rDNA from a range of other eukaryotes, and phylogenetic analyses were carried out using several inference methods. P. richardsi consistently and stably grouped within a novel clade that contains rDNAs from an apparently heterodisperse group of parasitic micro-organisms assigned to the class Ichthyosporea. P. richardsi is evidently misplaced in the genus Prototheca, and the authors propose its inclusion in a new genus Anurofeca.
\end{abstract}

Keywords: Prototheca, Anurofeca, Ichthyosporea, anuran growth inhibition

\section{INTRODUCTION}

Prototheca richardsi (Wong \& Beebee, 1994) is an enigmatic protist that has been implicated as a gut parasite of anuran larvae (e.g. Richards, 1962; Beebee, 1991). It mediates growth inhibition of tadpoles in the laboratory by means of interference competition (Beebee $\&$ Wong, 1992) and may play a role in determining the structure of natural anuran assemblages (Wong et al., 1994; Bardsley \& Beebee, 1998). Beebee \& Wong (1993) showed that cells of $P$. richardsi are stimulated to replicate by passage through tadpole digestive systems, and that their occurrence in natural ponds is correlated with the presence of anuran larvae (Wong et al., 1994).

The colourless, highly vacuolate unicellular eukaryote currently known as Prototheca richardsi was discovered in faeces of larval Rana pipiens by Richards (1958). Its

Abbreviation: ssu-rDNA, small-subunit (18S) ribosomal gene DNA The GenBank accession number for the sequence reported in this paper is AF070445. cells were later characterized as looking 'remarkably like chlorococcalean algae' (Richards, 1962), and H. J. Pfaff (personal communication to C.M. Richards) provisionally identified the organism as a member of the genus Prototheca. Algae of the genus Prototheca (Kruger, 1894) have spherical unpigmented cells $2-20 \mu \mathrm{m}$ in diameter, distinctive cell walls, and refractive, inclusion-bearing vacuoles that restrict the cytoplasm to the edges of the cell (Pore, 1985, 1986; Beebee, 1991). Mean cell size, utilization of carbon sources, and other growth parameters were consistent with classification of the anuran parasite in the genus Prototheca (Wong \& Beebee, 1994). Furthermore, DNA-RNA hybridization studies (Beebee, 1991) showed stronger heterologous binding with nucleic acids from a green alga (genus Dunaliella) than with those from yeast or protozoa (genera Saccharomyces and Acanthamoeba respectively).Wong \& Beebee (1994) thus established for this organism the status of a new species, $P$. richardsi.

Nonetheless, some inconsistencies remained with this identification. Antigenic cross-reactivity with cell preparations from four species of Prototheca was weak or 
Table 1. ssu-rDNAs used in phylogenetic analysis of the ssu-rDNA sequence from $P$. richardsi

\begin{tabular}{|c|c|c|}
\hline Species & Accession no. & Classification \\
\hline Xenopus laevis & $\mathrm{X} 04025$ & Metazoa \\
\hline Asterias amurensis & D14358 & Metazoa \\
\hline Brachionus plicatilis & $\mathrm{U} 29235$ & Metazoa \\
\hline Acanthopleura japonica & $X 70210$ & Metazoa \\
\hline Mytliis edulis & L24489 & Metazoa \\
\hline Lineus sp. & X79878 & Metazoa \\
\hline Eisenia fetida & X79872 & Metazoa \\
\hline Artemia salina & $\mathrm{X} 01723$ & Metazoa \\
\hline Eurypelma californica & $\mathrm{X} 13457$ & Metazoa \\
\hline Tripedalia cystophora & L10829 & Metazoa \\
\hline Mnemiopsis leidyi & L10826 & Metazoa \\
\hline Berö̈ cucumis & D15068 & Metazoa \\
\hline Microciona prolifera & L10825 & Metazoa \\
\hline Acanthocoepsis unguiculata & L10823 & Choanoflagellida \\
\hline Diaphanoeca grandis & L10824 & Choanoflagellida \\
\hline Neocallimastix sp. & M59761 & Fungi \\
\hline Spizellomyces acuminatus & M59759 & Fungi \\
\hline Chytridium confervae & M59758 & Fungi \\
\hline Aspergillus fumigatus & M60300 & Fungi \\
\hline Ustilago maydis & $\mathrm{X} 62396$ & Fungi \\
\hline Mucor racemosus & X54863 & Fungi \\
\hline Agent of amphibian chytridiomycosis & AF051932 & Fungi \\
\hline Psorospermium baeckelii & U33180 & Fungi/Metazoa incertae sedis \\
\hline Ichthyophonus hoferi & $\mathrm{U} 25637$ & Fungi/Metazoa incertae sedis \\
\hline Rosette agent & L29455 & Fungi/Metazoa incertae sedis \\
\hline Dermocystidium sp. & U21336 & Fungi/Metazoa incertae sedis \\
\hline Dermocystidium salmonis & U21337 & Fungi/Metazoa incertae sedis \\
\hline Acanthamoeba palestinensis & U07411 & Acanthamoebidae \\
\hline Acanthamoeba castellani & U07413 & Acanthamoebidae \\
\hline Cyanophora paradoxa & X68483 & Glaucocystopha \\
\hline Chlorella fusca & $X 74002$ & Viridiplantae \\
\hline Zamia purnila & M20017 & Viridiplantae \\
\hline Lagenidium giganteum & $\mathrm{X} 54266$ & Stramenophiles \\
\hline Rhizosolenia setigera & M87329 & Stramenophiles \\
\hline Synura spinosa & M87336 & Stramenophiles \\
\hline Tribonema aequale & M55286 & Stramenophiles \\
\hline Labyrinthuloides minuta & L27634 & Stramenophiles \\
\hline Labyrinthuloides haliotidis & $\mathrm{U} 21338$ & Stramenophiles \\
\hline Theileria buffeli & Z15106 & Alveolatea \\
\hline Sarcocystis muris & M64244 & Alveolatea \\
\hline Perkinsus sp. & L07375 & Alveolatea \\
\hline Perkinsus marinus & $X 75762$ & Alveolatea \\
\hline Porphyra spitalis & L26177 & Rhodophyta \\
\hline Palmaria palmata & Z14142 & Rhodophyta \\
\hline
\end{tabular}

nonexistent (Wong \& Beebee, 1994). Other protothecans can be cultured in vitro on Prototheca isolation medium (PIM) (Pore, 1973), whereas P. richardsi shows only weak growth. Indeed, $P$. richardsi can be cultured successfully only in the guts of anuran larvae (Wong \& Beebee, 1994), although it does replicate to a lesser extent in the guts of some other aquatic organisms such as the pond snail Limnaea stagnalis.
Over the past few decades systematics has been revolutionized by the introduction of molecular techniques (e.g. Hillis et al., 1996). Comparative analysis of sequences of rRNA genes has been particularly useful in elucidating phylogenetic relationships among microorganisms. Studies using small subunit rRNA gene (ssurDNA) sequences have been used to recognize new groups and reassign taxa at all levels, from domain 
(Woese et al., 1990) and phylum (Winnepenninckx et al., 1998) to genus and species.

We have reisolated $P$. richardsi from anuran larvae, amplified and sequenced its nuclear ssu-rDNA, and confirmed by in situ hybridization that the sequence is derived from the parasite. Comparative sequence analysis has demonstrated that $P$, richardsi is not an alga, but is a member of the Ichthyosporea (Cavalier-Smith, 1998), a newly recognized but previously untitled clade of protistan parasites near the animal-fungal divergence (Ragan et al., 1996).

\section{METHODS}

Purification of $\boldsymbol{P}$. richardsi cells. Cells of $P$. richardsi were purified from the faeces of Rana temporaria larvae raised in the laboratory under crowded conditions (after Beebee, 1991). The faecal isolates were then incubated in a cocktail of antibacterial and antifungal agents $(2 \%, \mathrm{w} / \mathrm{v}$, phthalic acid, $200 \mathrm{~g}^{2}$ streptomycin ml $\mathrm{l}^{-1}, 200$ units penicillin $\mathrm{ml}^{-1}, 0.025 \mathrm{mg} 5$ fluorocytosine $\mathrm{ml}^{-1}$ ) at $37^{\circ} \mathrm{C}$ for $24 \mathrm{~h}$. The suspension was then layered over a sterile Percoll gradient $(30 \mathrm{ml}$, density $1.04 \mathrm{~g} \mathrm{ml}^{-1}$ ) preformed by centrifugation at $48000 \mathrm{~g}$ for $60 \mathrm{~min}$ at $10^{\circ} \mathrm{C}$. The gradient was then centrifuged at $460 \mathrm{~g}$ for $30 \mathrm{~min}$ at $4^{\circ} \mathrm{C}$. The band of protothecans thus produced was carefully removed, washed with sterile water and incubated with $1 \mathrm{mg} \mathrm{DNase} \mathrm{ml}^{-1}$ (Sigma) in $10 \mathrm{mM}$ Tris/ $\mathrm{HCl} \mathrm{pH} \mathrm{8.3,}$ $50 \mathrm{mM} \mathrm{KCl}, 2 \mathrm{mM} \mathrm{MgCl}_{2}$ for $1 \mathrm{~h}$ at room temperature. This procedure was included to remove exogenous DNA fragments from any contaminating cells, especially those lysed by the previous antibiotic treatment. The DNase was deactivated at $65^{\circ} \mathrm{C}$ for $15 \mathrm{~min}$ and the cell suspension was then washed four times in sterile water. Finally the cells were pelleted at $4000 \mathrm{~g}$ and frozen at $-80^{\circ} \mathrm{C}$.

DNA extraction. The frozen $P$. richardsi cell pellets $\left(>10^{6}\right.$ cells) were ground under liquid nitrogen for $15 \mathrm{~min}$ with a mortar and pestle, and the resulting powder was incubated in $0.4 \mathrm{ml}$ of $1 \mathrm{mg}$ Protease $\mathrm{K} \mathrm{ml}^{-1}, 0.5 \%$ (w/v) SDS, $50 \mathrm{mM}$ Tris/ $\mathrm{HCl}, 0.4 \mathrm{M}$ EDTA $\mathrm{pH} 7.5$ for $2 \mathrm{~h}$ at $50^{\circ} \mathrm{C}$. This cell digest was then extracted with phenol/chloroform and precipated with ethanol (Beebee \& Wong, 1993). The genomic DNA pellet was then resuspended and purified further using the Qiagen 20 kit, following the manufacturer's instructions. The final DNA pellet was dissolved in sterile water at approximately $200 \mathrm{ng} \mathrm{l}^{-1}$.

Amplification, cloning and sequencing of genomic DNA. The nuclear ssu-rDNA was amplified from purified $P$. richardsi genomic DNA by PCR using eukaryote-specific primers (Medlin et al., 1988). Amplification products from three separate faecal isolates were purified using a Qiagen PCR clean-up kit and were cloned using the Invitrogen TA cloning kit following the manufacturer's protocol. Two non-sibling clones from each faecal isolate were sequenced using the universal ssu-rRNA primers described by Elwood et al. (1985) on an Applied Biosystems 370A automated DNA sequencer.

In situ hybridization. To ensure that the amplified DNA originated from the $P$. richardsi cells, in situ hybridization was conducted following the method of DeLong et al. (1989). Three fluorescein-labelled DNA oligonucleotides were synthesized for use as hybridization probes. The first (TB01) was a 17 bp fragment of conserved small-subunit rRNA sequence (Elwood et al., 1985), which acted as a negative control to test for non-specific hybridization and fluorescence. Although this probe would hybridize to the complementary strand of rDNA, only the rRNA transcription product is present in cells in sufficient quantity to register by in situ hybridization. The second probe (TB02) was a $15 \mathrm{bp}$ oligonucleotide that is universally complementary to a conserved region of nuclear ssu-rRNA (Elwood et al., 1985). The third probe (TB03) was an 18 bp sequence designed to be complementary to a unique region of $P$. richardsi ssu-rRNA. All probes were checked for complementarity to all rRNA sequences in the small-subunit and large-subunit databases using the Check Probe program from the Ribosomal Database Project (Maidak et al., 1997).

The probes were hybridized with tadpole faecal isolates and human IB4 B cells (obtained from Dr Alison Sinclair) fixed on to glass slides (after DeLong et al., 1989), and were examined by epifluorescence and phase-contrast microscopy. The relative fluorescences of $P$. richardsi cells and human cells were compared for each of the hybridizations.

Sequence analysis. The consensus sequence of the ssu-rDNA from the six clones was aligned by eye with ssu-rDNAs from representative taxa from the eukaryotic crown (Table 1). Nucleotide substitution rates were estimated for this alignment using TReECON (Van de Peer \& De Wachter, 1994). Distances based on the substitution rate function were used to infer a neighbour-joining tree, and analyses were bootstrapped $(n=100)$ in TREECON. Neighbour-joining, parsimony and maximum-likelihood trees were also inferred using PHYLIP 3.53c (Felsenstein, 1989); multiple iterations $(n=1000)$ were made to increase the likelihood of finding maximally parsimonious trees, and parsimony analyses were bootstrapped $(n=1000$; except likelihood, where $n=100)$. The maximumlikelihood trees were inferred under a range of transition/ transversion ratios between 1.50 and 2.50. To root the trees, Chlorella fusca was set as the outgroup in TREECON analyses, and Perkinsus marinus was used in PHYLIP analyses. Topology within and among animals, fungi, Ichthyosporea and stramenophiles was not influenced by choice of either of these sequences as outgroup. Bootstrapped analyses were carried out on multiprocessor Sun Enterprise 4001 servers in the Canadian Bioinformatics Resource at IMB-NRC.

\section{RESULTS}

\section{Sequence determination}

The sequence of ssu-rDNA from Prototheca richardsi was determined for six separate clones (two from each of three isolates). Sequence variation between clones was no more than two out of a total of 1802 nucleotides. These two sites were at positions 93 and 933. The consensus sequence was deposited in GenBank (accession number AF070445).

The purification procedure used to isolate $P$. richardsi from tadpole faeces prior to DNA extraction yielded cell suspensions lacking visible contaminants (Fig. 1a). However, it was important to be sure that the DNA subsequently extracted and sequenced definitely came from $P$. richardsi. In situ hybridizations using specific oligonucleotide probes were therefore carried out. For these studies it was necessary to use relatively crude faecal isolates, because the long Prototheca purification procedure reduced signal strength substantially (probably on account of target RNA degradation). Nevertheless, the in situ hybridizations confirmed that the 

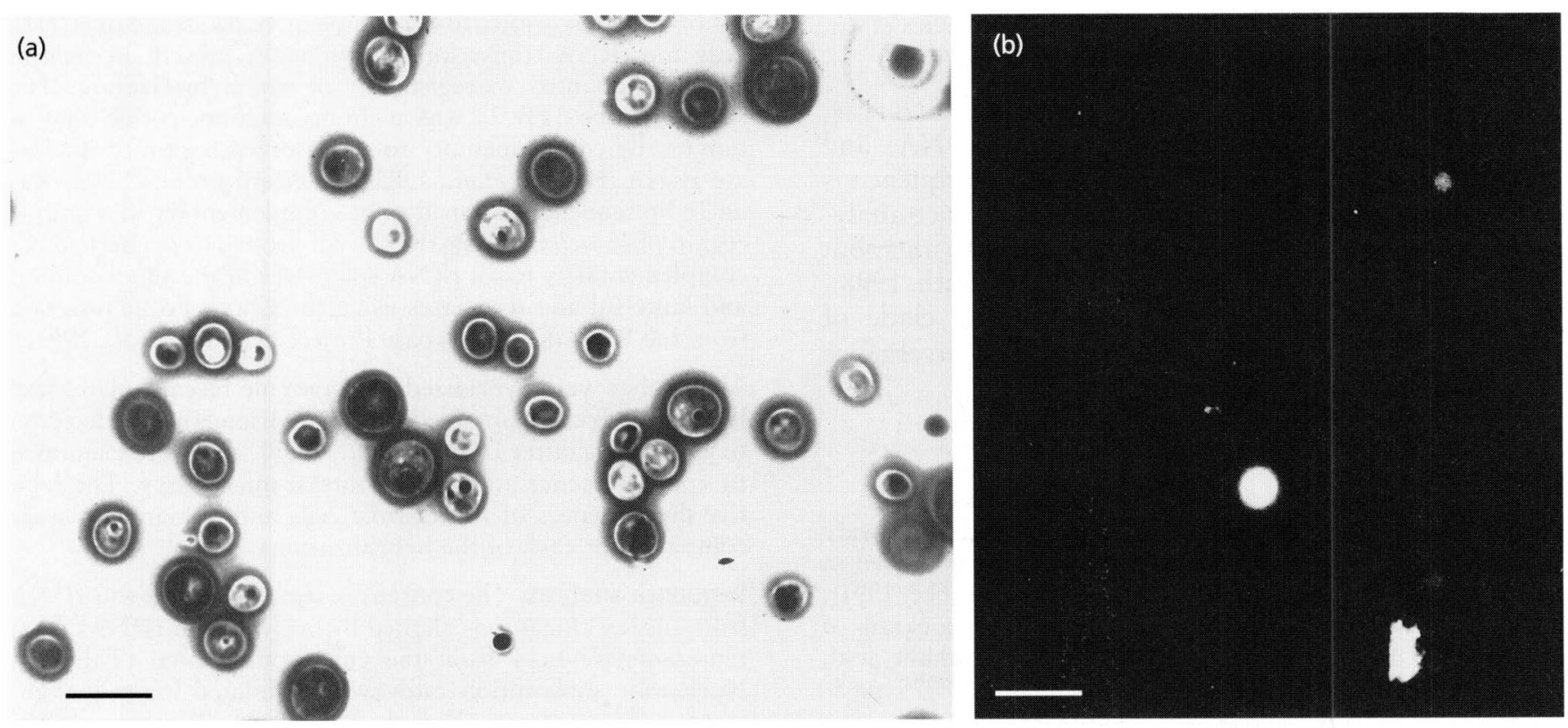

Fig. 1. (a) Phase-contrast microscopy of Prototheca cells after purification from tadpole faeces; (b) fluorescence of Prototheca cells (two in-frame) after hybridization with Prototheca-specific probe TB03. Bars, $10 \mu \mathrm{m}$.

Table 2. In situ hybridization test of ssu-rDNA source

\begin{tabular}{|lcc|}
\hline Probe & \multicolumn{2}{c|}{ Hybridization* to: } \\
\cline { 2 - 3 } & $\begin{array}{c}\text { P. richardsi } \\
\text { in faeces }\end{array}$ & $\begin{array}{c}\text { Human IB4 } \\
\text { cells }\end{array}$ \\
\hline $\begin{array}{l}\text { TB01 (negative control) } \\
\text { 5'-CTGGTTGATCCTGCCAG-3' }\end{array}$ & - & - \\
TB02 (positive control) & ++ & +++ \\
5'-AGAATTTCACCTCTG-3' & & - \\
TB03 (P. richardsi specific) & +++ & - \\
5'-ATGCTTGGAGTGCCGGCT-3' & & \\
\hline
\end{tabular}

* Weak non-specific fluorescence signal; ++ , strong signal; +++ , very strong signal.

DNA amplified and sequenced was derived from the $P$. richardsi cells. A low background of nonspecific fluorescence was observed in all hybridizations, including those with the negative control probe. Prototheca and human cells fluoresced when hybridized with the universal positive control probe (data not shown), but only $P$. richardsi cells fluoresced when hybridized with the $P$. richardsi probe (Fig. 1b). Table 2 summarizes results from three replicated experiments.

\section{Phylogenetic analyses}

On the basis of rRNA sequence analysis, $P$. richardsi was clearly unrelated to the other protothecans, all of which cluster with Chlorella (Huss \& Sogin, 1990). We confirmed the separation of $P$. richardsi from other protothecans in preliminary analyses which included $P$. wickerhamii, P. zopfii and Chlorella protothecoides rDNA sequences. Trees inferred by neighbour-joining clustered the three above protothecans together in a clade separate and distant from one including $P$. richardsi (data not shown). In all inferred trees (neighbour-joining in both TREECON and PHYLIP, parsimony, and maximum-likelihood) the ssu-rDNA from $P$. richardsi grouped stably with ssu-rDNAs from Ichthyophonus hoferi, Psorospermium haeckelii, Dermocystidium salmonis, Dermocystidium sp., and the rosette agent of salmon. Within this clade, provisionally termed the DRIPs clade (as an acronym for Dermocystidium, rosette, Ichthyophonus and Psorospermium) by Ragan et al. (1996) and assigned to class Ichthyosporea by Cavalier-Smith (1998), the ssu-rDNA from P. richardsi 


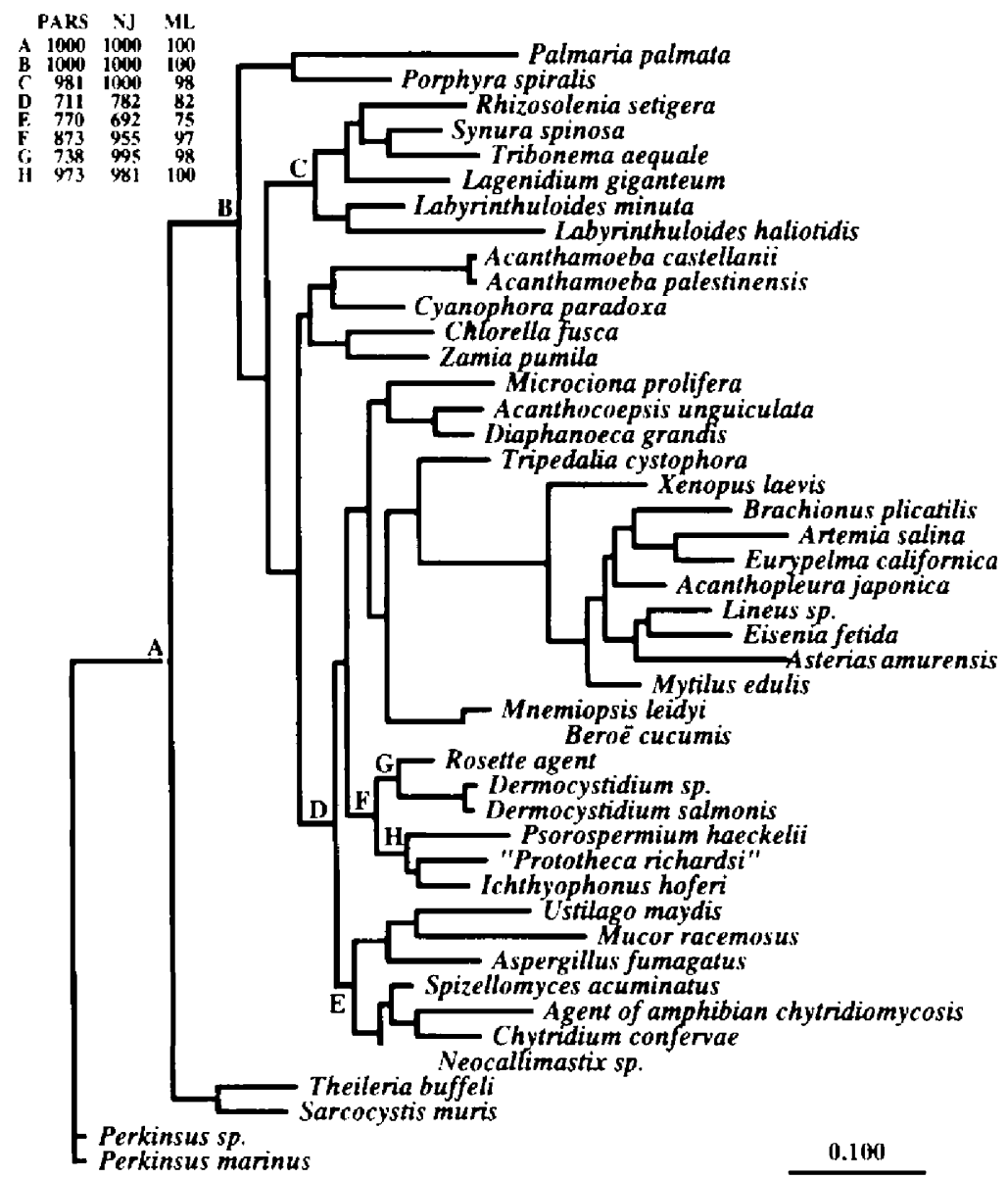

Fig. 2. Phylogenetic relationship among ssu-rDNAs. The tree shown was inferred by maximum-likelihood at transition/ transversion ratio 2.00 with full (43-level) optimization. GenBank accession numbers for the ssu-rDNAs are given in Table 1 . Bootstrap values (upper left) reflect the number of replicate analyses in which the grouping subtended by the indicated node appeared after resampling the alignment with replacement. PARS, parsimony $(n=$ 1000); NJ, neighbour-joining $(n=1000)$ : $\mathrm{ML}$, maximum-likelihood $(n=100)$. The scale bar represents 0.1 likelihood units as estimated by DNAML (in PHYLIP). always grouped with those of $I$. hoferi and Psorospermium haeckelii (Fig. 2). Analysis of the data using a substitution calibration also yielded this clade with a bootstrap value of $99 \%$ on a neighbour-joining tree.

The Ichthyosporea clade appeared intact as the optimal solution under all methods of inference. Bootstrap support was $>97 \%$ with maximum-likelihood, $>95 \%$ with neighbour-joining, and $>87 \%$ in parsimony analysis. These values are comparable with the 76-99\% (neighbour-joining) and 60-79\% (parsimony) bootstrap values recorded by Ragan et al. (1996) based on a more conservative selection of sequence positions. Within the Ichthyosporea clade, bootstrap support for the grouping of Prototheca richardsi, I. hoferi and Psorospermium baeckelii ssu-rDNAs was even higher, ranging from $>97 \%$ in parsimony to $100 \%$ in maximum-likelihood. The $P$. richardsi ssu-rDNA specifically grouped with the ssu-rDNA from $I$, hoferi in parsimony, maximumlikelihood and rate-uncalibrated neighbour-joining analyses (Fig. 2), whereas it formed a sister clade to ssurDNAs from Psorospermium haeckelii and $I$. hoferi in a rate-calibrated neighbour-joining analysis (results not shown). In the regions (1622 nucleotides) multiply aligned for the phylogenetic inference, the ssu-rDNA of $P$. richardsi was $91.9 \%$ identical to that of $I$. hoferi and $87.8 \%$ identical to that of Psorospermium haeckelii, after correction for superimposed changes under the maximum-likelihood model of Felsenstein (1981). In these same regions, the ssu-rDNAs of 1 . hoferi and Psorospermium haeckelii were $89 \cdot 0 \%$ identical.

\section{DISCUSSION}

Prototheca richardsi occurs naturally as a gut parasite of anuran larvae, and has yet to be cultured successfully in vitro. Attempts to establish cultures of $P$. richardsi have been plagued by its weak growth on defined isolation media (including Prototheca isolation medium), and by contamination with bacteria and filamentous fungi (Wong \& Beebec, 1994). As it is well known that even low levels of contaminant DNAs (e.g. from the host amphibian or from other gut organisms) can be amplified by PCR with universal primers, we performed in situ hybridizations to confirm the source of the ssurDNA sequence we obtained. Our results established that the DNA sequenced did derive from cells of $P$. richardsi. These results were reinforced by our phylogenetic analyses, which confirmed that this ssu-rDNA was not of fungal or vertebrate origin.

The phylogenetic trees inferred from ssu-rDNA sequences also indicated that $P$. richardsi is not an alga. The initial placement of this organism in the genus Prototheca was based on morphology, physiology and nucleic acid hybridization data. Comparative sequence 
Table 3. Members of the Ichthyosporea

\begin{tabular}{|c|c|c|c|c|}
\hline Species & Morphology & Life history & Hosts & References \\
\hline $\begin{array}{l}\text { Dermocystidium } \\
\text { spp. }(>20)\end{array}$ & $\begin{array}{l}\text { (i) } 5-15 \text { spherical cells with } \\
\text { vacuoles and refractile } \\
\text { inclusions, and peripheral } \\
\text { nucleus; (ii) septate hyphae; } \\
\text { (iii) uniflagellate zoospores }\end{array}$ & $\begin{array}{l}\text { Cause systemic infections, } \\
\text { gill and skin cysts; } D \text {. } \\
\text { salmonis is transmitted by } \\
\text { zoospores }\end{array}$ & Fish, newts, frogs & $\begin{array}{l}\text { Olson et al. (1991); } \\
\text { Paperna \& Kim (1996); } \\
\text { Ragan et al. }(1996)\end{array}$ \\
\hline Rosette agent & $\begin{array}{l}3-7 \text { spherical cells with cell } \\
\text { wall }\end{array}$ & $\begin{array}{l}\text { Intracellular, spleen and } \\
\text { kidney; divides by fission }\end{array}$ & Chinook salmon & Kerk et al. (1995) \\
\hline $\begin{array}{l}\text { Psorospermium } \\
\text { baeckelii }\end{array}$ & $\begin{array}{l}\text { Egg-shaped spores, } \\
100 \times 60 \times 60 \mu \mathrm{m}\end{array}$ & Within connective tissue & $\begin{array}{l}\text { Crayfish, amphipods, } \\
\text { scyphozoans }\end{array}$ & Vogt \& Rug (1995) \\
\hline $\begin{array}{l}\text { Ichthyphonus } \\
\text { hoferi }\end{array}$ & $\begin{array}{l}\text { (i) Hyphae (similar to } \\
\text { Saprolegnia); (ii) binucleate } \\
\text { bodies; (iii) multinucleate } \\
\text { spores with thick cell walls, } \\
\text { up to } 200 \mu \mathrm{m}\end{array}$ & $\begin{array}{l}\text { In multiple organs, including } \\
\text { muscle; white lesions on } \\
\text { liver and kidney; spores } \\
\text { divide by fission; } \\
\text { transmission by hyphae }\end{array}$ & $\begin{array}{l}80 \text { spp. of fish, } \\
\text { newts, reptiles, } \\
\text { birds, crustaceans }\end{array}$ & $\begin{array}{l}\text { Herman (1984); Rand } \\
(1990,1994) ; \text { Spangaard } \\
\text { et al. }(1994,1995,1996)\end{array}$ \\
\hline $\begin{array}{l}\text { Prototheca } \\
\text { richardsi }\end{array}$ & $\begin{array}{l}\text { 1-10 spherical cells, with } \\
\text { vacuoles and refractive } \\
\text { inclusions, and peripheral } \\
\text { nucleus }\end{array}$ & $\begin{array}{l}\text { Within guts, and transmitted } \\
\text { in faeces }\end{array}$ & Anuran larvae & $\begin{array}{l}\text { Richards (1962); Beebee } \\
\text { (1991); Wong \& Beebee } \\
\text { (1994) }\end{array}$ \\
\hline
\end{tabular}

analysis is more robust than these methods, and provides much greater resolving power for clade identification. We propose that this organism should be removed from the genus Prototheca and placed appropriately within the Ichthyosporea (Cavalier-Smith, 1998). This class was created to accommodate a recently recognized clade of protists having a phylogenetic position near the animal-fungal divergence. Provisionally referred to as the DRIPs clade by Ragan et al. (1996), it comprises five species/groups of species: Dermocystidium salmonis, Dermocystidium sp., the rosette agent, Ichthyophonus hoferi, and Psorospermium haeckelii. In most ssu-rDNA trees these organisms are further subdivided into a Dermocystidium/rosette group and an Ichthyophonus/ Psorospermium group. All five species are parasites of aquatic organisms, but very little is known about their life histories (Table 3). Based on a $520 \mathrm{bp}$ partial sequence of nuclear ssu-rDNA, J.P. Joestensen, $S$. Johansen \& R. Landfald (unpublished, see GenBank accession Y16260) have put forward Sphaerosoma arcticus as a sixth member of the Ichthyosporea.

The genus Dermocystidium has been used as a repository for a number of poorly characterized parasitic organisms (Ragan et al., 1996). Members of Dermocystidium have been described as haplosporeans, fungi and apicomplexa (Paperna \& Kim, 1996; Ragan et al., 1996). The rosette agent, an obligate intracellular parasite of the chinook salmon Oncorbynchus tshawytscha, was discovered in the mid-1980s. Systematists previously believed the rosette agent to have phylogenetic affinities with the fungi and colourless algae (Kerk et al., 1995). Psorospermium haeckelii, first described in 1883 , has previously been described as a sporozoan, a histopathogenic stage of a fungus, and an alga. The genus Ichthyophonus has been used as a repository for a wide range of fish parasites, and has been classified within or near taxa today known as Chytridiomycetes, Zygomycetes, Ascomycetes, Oomycetes, Apicomplexa, Haplosporida and Myxozoa (Ragan et al., 1996; Spangaard et al., 1996). It seems unlikely that any existing genus within Ichthyosporea is appropriate to accommodate $P$. richardsi, and therefore a new genus will probably have to be created.

On the basis of morphology alone, the class Ichthyosporea (including, as shown above, $P$. richardsi) seems an unlikely taxonomic grouping. Comparative analysis of ssu-rDNA sequences indicates, however, that these organisms share a common ancestry. The presence of hyphae and flagella in other members of Ichthyosporea suggests that $P$. richardsi may also have more than one life-history stage. The development of specific oligonucleotide probes complementary to unique regions of the ssu-rDNA offers one avenue for investigation of other life stages in this organism.

The current taxonomy of eukaryotes derived from ssurRNA sequences places the fungi, animals, choanoflagellates and several protists incertae sedis in a group together known as the Metazoa/fungi group or Opisthokonta (Cavalier-Smith \& Allsopp, 1996). The branching order of taxa within the Opisthokonta and between other taxa within the eukaryote crown, however, remain largely unresolved (Van de Peer \& De Wachter, 1997). The nodes in the eukaryotic crown are each separated by fewer than five nucleotide changes per 1000 bases, making branching order difficult to establish (Wainright et al., 1993). On the basis of ssu-rRNA sequences, the Metazoa is monophyletic; its members share a most recent common ancestor with choanoflagellates, but the phylogenetic position of the choanoflagellates within the Opisthokonta is unstable (Wainright et al., 1993; Van de Peer \& De Wachter, 1997). 
$P$. richardsi is a potent growth inhibitor of anuran larvae in the laboratory (Beebee, 1991) and can affect the mortality of anuran larvae in the field under certain environmental conditions (Baker \& Beebee, 1997). High titres of $P$. richardsi have been found in tadpoles in natural ponds, and in pond sediments (Wong et al., 1994; Bardsley \& Beebee, 1998). Global declines of amphibian populations have increasingly been ascribed to pathogenic micro-organisms (e.g. Cunningham, 1996; Laurance et al., 1996; Berger et al., 1998), and the further study of these agents may be of critical importance in future conservation efforts. As shown in Fig. 2 , the agent of amphibian chytridiomycosis characterized by Berger et al. (1998) is in a clade quite separate from the Ichthyosporea. Prototheca richardsi is however clearly not a protothecan, and we propose that it should be renamed in a novel genus as Anurofeca richardsi. Apart from the ssu-rDNA sequence, $P$. richardsi is distinct from other members of the genus Prototheca in two other ways: (1) its cell surface is immunologically differentiated from that of other protothecans, and antibodies raised against it do not cross-react with the other protothecan species; and (2), unlike all other protothecans, P. richardsi will not grow on Prototheca isolation medium (Wong \& Beebee, 1994). We further justify a novel genus because the morphology of $P$. richardsi is quite unlike that of $I$. hoferi, its apparent closest relative (Table 3 ). Also, the ssu-rDNA sequence differences between $P$. richardsi and I. hoferi $(8 \cdot 1 \%)$ and between $P$. richardsi and Psorospermium haeckelii $(12.2 \%)$ are comparable with the difference between $I$. hoferi and Psorospermium haeckelii $(11.0 \%)$, two organisms already accepted as being in separate genera.

\section{Formal description}

\section{Proposed genus: Anurofeca}

Diagnosis: Unicellular eukaryote; spherical, highly vacuolated cells of $3-10 \mu \mathrm{m}$ diameter; unpigmented; non-motile.

Type species: richardsi. Holotype deposited in algal slide collection, British Natural History Museum, London (as Prototheca richardsi : slide BM/B/12899).

Full description: Mature cells are $7-10 \mu \mathrm{m}$ in diameter, with a cell wall $0 \cdot 5-1 \mu \mathrm{m}$ thick and electron-dense vacuoles occupying at least $50 \%$ of the cell volume. A peripheral nucleus is usually visible, but mitochondria are rarely identifiable under transmission electron microscopy. No chlorophyll or other pigmentation is present. Reproduction by fission generates multicellular conglomerates (2-8 cells together), with daughter cells

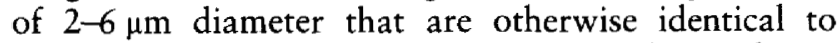
mature cells. All cells are non-motile, without cilia or flagella.

\section{ACKNOWLEDGEMENTS}

We thank the Biotechnology and Biological Sciences Research Council for a studentship for G. C. Baker, Dr Alison Sinclair for provision of the human IB4 B cells and Dr Alan Warren
(British Museum) for advice on formal genus description. This paper is issued as NRCC no. 42278.

\section{REFERENCES}

Baker, G. C. \& Beebee, T. J. C. (1997). Microenvironmental effects on competition between Rana and Bufo larvae, and on the abundance of Prototheca richardsi, in small fish ponds. Herpetol J 7, 149-154.

Bardsley, L. \& Beebee, T. J. C. (1998). Interspecific competition between $B$ ufo larvae under conditions of community transition. Ecology 79, 1751-1760.

Beebee, T. J. C. (1991). Purification of an agent causing growth inhibition in anuran larvae and its identification as anicellular alga. Can J Zool 69, 2146-2153.

Beebee, T. J. C. \& Wong, A. L.-C. (1992). Prototheca mediated interference competition between anuran larvae operates by resource diversion. Physiol Zool 65, 815-831.

Beebee, T. J. C. \& Wong, A. L.-C. (1993). Stimulation of cell division and DNA replication in Prototheca richardsi by passage through larval amphibian guts. Parasitology 107, 119-124.

Berger, L., Speare, R., Daszak, P. \& 11 other authors (1998). Chytridiomycosis causes amphibian mortality associated with population declines in the rain forests of Australia and Central America. Proc Natl Acad Sci USA 95, 9031-9036.

Cavalier-Smith, T. (1998). Neomonada and the origin of animals and fungi. In Evolutionary Relationships among Protozoa, pp. 375-407. Edited by G. H. Coombs, K. Vickerman, M. A. Sleigh \& A. Warren, London: Chapman \& Hall.

Cavalier-Smith, T. \& Allsopp, M. T. E. P. (1996). Corallochytrium, an enigmatic non-flagellate protozoan related to choanoflagellates. Eur J Protistol 32, 306-310.

Cunningham, A. A. (1996). Disease risks of wildlife translocations. Conserv Biol 2, 349-353.

DeLong, E. F., Wickham, G. S. \& Pace, N. R. (1989). Phylogenetic stains: ribosomal RNA-based probes for the identification of single cells. Science 243, 1360-1363.

Elwood, H. J., Olsen, G. J. \& Sogin, M. L. (1985). The smallsubunit ribosomal RNA gene sequences from the hypotrichopus ciliates Oxytricha nova and Stylonychia pustulata. Mol Biol Evol 2, 399-410.

Felsenstein, J. (1981). Evolutionary trees from DNA sequences: a maximum likelihood approach. $J$ Mol Evol 17, 368-376.

Felsenstein, J. (1989). PHYLIP - Phylogeny Inference Package. Cladistics 5, 164-166.

Herman, R. L. (1984). Ichthyophonus-like infection in newts (Notophthalmus viridescens Rafinesque). J Wildlife Dis 20, $55-56$.

Hillis, D. M., Moritz, C. \& Mable, B. K. (1996). Molecular Systematics, 2nd edn. Sunderland, MA: Sinauer Associates.

Huss, V. A. R. \& Sogin, M. L. (1990). Phylogenetic position of some Chlorella species within the Chlorococcales based on complete small-subunit ribosomal RNA sequences. Evolution 31, 432-442.

Kerk, D., Gee, A., Standish, M., Wainwright, P. O., Drum, A. S., Elston, R. A. \& Sogin, M. L. (1995). The rosette agent of chinook salmon (Oncorrbynchus tshawytscha) is closely related to the choanoflagellates, as determined by the phylogenetic analyses of its small ribosomal subunit RNA. Mar Biol 122, 187-192.

Kruger, W. (1894). Kurze Charakteristik einiger niederer Organismen in Saftflusse der Laubbaume. Hedwigia 33, 241-266.

Laurance, W. F., McDonald, K. R. \& Speare, R. (1996). Epidemic 
disease and the catastrophic decline of Australian rain forest frogs. Conserv Biol 10, 406-413.

Maidak, B. L., Olsen, G. J., Larsen, N., Overbeek, R., McCaughey, J. \& Woese, C. R. (1997). The RDP (ribosomal database project). Nucleic Acids Res 25, 109-110.

Medlin, L., Elwood, H. J., Stickel, S. \& Sogin, M. L. (1988). The characterisation of enzymatically amplified eukaryotic 16S-like rRNA coding regions. Gene 71, 491-499.

Olson, R. E., Dungan, C. F. \& Holt, R. A. (1991). Water-borne transmission of Dermocystidium salmonis in the laboratory. Dis Aquat Org 12, 41-48.

Paperna, I. \& Kim, S.-H. (1996). Ultrastructure of the aetiological agent of systemic granuloma in goldfish. Dis Aquat Org 26, $43-47$.

Pore, R. S. (1973). Selective medium for the isolation of Prototheca. Appl Microbiol 26, 648-649.

Pore, R. S. (1985). Prototheca taxonomy. Mycopathologica 90, 129-139.

Pore, R. S. (1986). The association of Prototheca spp. with slime flux in Ulmus americana and other trees. Mycopathologia 94, 67-73.

Ragan, M. A., Goggin, C. L., Cawthorn, R. J., Cerenius, L., Jamieson, A. V. C., Plourde, S. M., Rand, T. G., Söderhäll, K. \& Gutell, R. R. (1996). A novel clade of protistan parasites near the animal-fungal divergence. Proc Natl Acad Sci USA 93, 11907-11912.

Rand, T. G. (1990). Studies on the biology of Ichthyophonus hoferi Plehn and Mulsow, 1911 from Nova Scotian yellowtail flounder, Limanda ferruginea (Storer). PhD thesis, University of New Brunswick, Fredericton.

Rand, T. G. (1994). An unusual form of Ichthyophonus hoferi from yellowtail flounder Limanda ferruginea from the Nova Scotia shelf. Dis Aquat Org 18, 21-28.

Richards, C. M. (1958). Inhibition of growth in crowded Rana pipiens tadpoles. Physiol Zool 16, 138-151.

Richards, C. M. (1962). The control of tadpole growth by alga-like cells. Physiol Zool 35, 285-296.

Spangaard, B., Gram, L., Okamoto, N. \& Huss, H. H. (1994).
Growth of the fish-pathogenic fungus, Ichthyophonus boferi, measured by conductimetry and microscopy. J Fish Dis 17, 145-153.

Spangaard, B., Huss, H. H. \& Bresciani, J. (1995). Morphology of Ichtbyophonus hoferi assessed by light and scanning electron microscopy. J Fish Dis 18, 567-577.

Spangaard, B., Skouboe, P., Rossen, L. \& Taylor, J. W. (1996). Phylogenetic relationships of the intercellular fish pathogen Ichtbyophonus hoferi, and fungi, choanoflagellates and the rosette agent. Marine Biol 126, 109-115.

Van de Peer, Y. \& DeWachter, R. (1994). TREECON for windows: a software package for the construction and drawing of evolutionary trees for the Microsoft Windows environment. Comput Appl Biosci 10, 569-570.

Van De Peer, Y. \& De Wachter, R. (1997). Evolutionary relationships among the eukaryotic crown taxa taking into account siteto-site rate variation in 185 rRNA. $J$ Mol Evol 45, 619-630.

Vogt, G. \& Rug, M. (1995). Microscopic anatomy and histochemistry of the crayfish parasite Psorospermium haeckelii. Dis Aquat Org 21, 79-90.

Wainright, P. O., Hinkle, G., Sogin, M. L. \& Stickel, S. K. (1993). Monophyletic origins of the Metazoa : an evolutionary link with fungi. Science 260, 340-342.

Winnepenninckx, B. M. H., Backeljau, T. \& Kristensen, R. L. (1998). Relations of the new phylum Cycliophora. Nature 393, 636-638.

Woese, C. R., Kandler, O. \& Wheelis, M. L. (1990). Towards a natural system of organisms: proposal for the domains Archaea, Bacteria, and Eucarya. Proc Natl Acad Sci USA 87, 4576-4579.

Wong, A. L.-C. \& Beebee, T. J. C. (1994). Identification of a unicellular, non-pigmented alga that mediates growth inhibition in tadpoles: a new species of the genus Prototheca (Chlorophyceae: Chlorococcales). Hydrobiologia 277, 85-96.

Wong, A. L.-C., Beebee, T. J. C. \& Griffiths, R. A. (1994). Factors affecting the distribution and abundance of an unpigmented heterotrophic alga. Freshwater Biol 32, 33-38.

Received 2 December 1998; revised 23 March 1999; accepted 1 April 1999. 